MANAGEMENTACCOUNTING PLANNINGENCONTROL O ONDERZOEK

\title{
Kritieke succesfactoren: een pilot-study in de Nederlandse industrie
}

Dr. M.F.C.M.Wijn, Drs. W.A. Hofenk, Drs. R.W. Hoekstra en M.B. Hengeveld B. ec.

\section{Inleiding ${ }^{\mathrm{I}}$}

Vele ondernemingen worden geconfronteerd met een sterke toename van de internationale concurrentie. Als gevolg hiervan zijn de winstmarges kleiner geworden waardoor strategische misrekeningen veel ernstiger gevolgen hebben voor ondernemingen dan in het verleden het geval was. Door gebruik te maken van een doelmatig beheerssysteem kan tijdig op snel veranderende omstandigheden worden ingespeeld. Om beter grip te krijgen op de toestand waarin de onderneming verkeert, is inzicht nodig in de factoren die kunnen bijdragen tot het succes van de onderneming.

Bij een groot aantal ondernemingen blijken de interne beheerssystemen echter ernstig tekort te schieten (Johnson, 1992; Lewy, 1992). Door het definiëren en monitoren van een beperkt aantal kritieke succesfactoren ( $k s f-e n$ ) moeten managers beter in staat zijn om de resultaten van de onderneming te beoordelen. Kritieke succesfactoren zijn die variabelen (factoren) die aangeven hoe een onderneming op de lange termijn waarde kan genereren en voldoende winstgevend kan zijn (Atkinson et al. 1995, Wijn et al. 1994). Voor het interne beheerssysteem worden van de ksf-en meetpunten, de kritieke stuurvariabelen, afgeleid. Het merendeel van de onderzoeken komt per onderneming uit op ongeveer zes ksf-en.

De auteurs zijn als respectievelijk universitair hoofddocent, toegevoegd onderzoeker, toegevoegd docent en studentassistent verbonden aan de sectie Kosten, Waarde en Winst, vakgroep Bedrijfseconomie, Faculteit der Economische Wetenschappen, KU Brabant.
Als meest genoemde ksf-en komen in onze pilot-study onder industriële ondernemingen in Nederland naar voren: (a) prijs/efficiency, (b) kwaliteit, (c) flexibiliteit, (d) innovatie, en (e) service. Naast ksf-en die voor meerdere ondernemingen gelden, blijken er ook ksf-en te zijn die alleen voor een enkel bedrijf van toepassing zijn. De kwaliteit van het management kan als een alles overkoepelende ksf worden beschouwd.

\section{Afbakening van het begrip kritieke succesfactoren}

In de literatuur blijkt er sprake te zijn van een Babylonische spraakverwarring over het begrip kritieke succesfactoren (zie onder andere: Daniel, 1961: Rockart, 1979; Boynton en Zmud, 1984; Leidecker en Bruno, 1984; Krijnen en Geven, 1991; De Waal en Bulthuis, 1993). In hun definities van ksf-en wordt niet duidelijk aangegeven wat moet worden verstaan (a) onder het kritieke aspect van de succesfactor en (b) wat onder succes moet worden verstaan.

Wij definiëren ksf-en als: "De factoren op hasis waarvan een onderneming zich ten opzichte van de concurrentie kan onderscheiden om aldus een duurzame positieve relatie met de markt op te bouw'en". Onder een "duurzame positieve relatie met de markt" moet worden verstaan dat de markt blijvend een beroep zal doen op de onderneming voor het leveren van produkten en/of diensten tegen een voor de onderneming bevredigend rendement (Hofenk en Wijn, 1994). De onderneming kan hierdoor haar activiteiten continueren.

Het aantal factoren wat van invloed kan zijn op het voortbestaan van een onderneming is in feite onoverzienbaar en bijna onbeperkt. De mens 
is echter begrensd in zijn mogelijkheden en kan derhalve slechts een beperkt aantal (succes)factoren overzien. Over het aantal ksf-en dat de manager in de praktijk zou hanteren, bestaat in de literatuur geen eenstemmigheid. Lewy (1992) stelt, dat het meestal gaat om één, twee of hooguit drie werkelijk belangrijke factoren. Anthony et al. $(1989,1992)$ komen op drie tot zes, terwijl Hahn en Krystek (1979) uitgaan van zes tot acht ksf-en. De meeste publikaties komen uit op zes.

\section{Factoren die van invloed zijn op verschillen in ksf-en tussen ondernemingen}

Er is in het verleden al onderzoek gedaan naar de factoren die bepalend kunnen zijn voor de ksf-en van ondernemingen. Als meest belangrijke factoren zijn aangemerkt $\left.{ }^{2}: 1\right)$ omgevingsfactoren, zoals bijvoorbeeld bruto nationaal produkt. veranderde politieke omstandigheden, enz., 2) bedrijfstak, 3) leveranciers, 4) afnemers, 5) concurrentiepositie en 6) schaalgrootte.

Rockart (1979) voegt aan dit rijtje nog factoren van intern-organisatorische aard toe. Het gaat hierbij om factoren die op korte termijn van essentieel belang zijn voor het voortbestaan van een onderneming. Het betreft zeer extreme bedrijfsomstandigheden. zoals bijvoorbeeld het wegvallen van een groot aantal topmanagers als gevolg van een vliegtuigongeluk of het niet tijdig kunnen leveren als gevolg van stakingen.

Over wat de invloed is van de strategie op de ksf-en zijn de meningen verdeeld. Volgens Rockart (1979), Boynton en Zmud (1984). Anthony et al. $(1989,1992)$ is de strategie bepalend voor de te gebruiken ksf-en. Eerst moet(en) de lange termijn doelstelling(en) worden bepaald en daarop word de te volgen strategie afgestemd. De ksf-en worden vervolgens gebaseerd op de gekozen strategie. Volgens Atkinson et al. (1995), Leidecker en Bruno (1984) en Ohmae (1982), wij sluiten ons bij hen aan, moeten juist de ksf-en gebaseerd zijn op de lange termijn doelstellingen en worden de strategische beslissingen afgeleid van de ksf-en. Overeenkomstig de door ons gekozen definitie van ksf-en worden de factoren die van invloed zijn op het succes van de onderneming door de markt ingegeven. De ksf-en zijn derhalve bepalend voor de door de onderneming te kiezen strategie.

\section{Implementatie van ksf-en; de kritieke stuurvariabelen}

Nadat de ksf-en zijn vastgesteld moeten deze worden opgenomen in het interne beheerssysteem en worden bewaakt met behulp van kengetallen en/of andere indicatoren. De relevante bedrijfsprocessen moeten worden gekoppeld aan de vastgestelde ksf-en. Op deze wijze kan voor het management de informatiebehoefte worden bepaald (voor een hiervoor geschikte methodiek wordt verwezen naar Van Snellenberg, 1992a en Ward, 1990). De ontwikkelde maatstaven zijn de belangrijkste meetpunten voor het reilen en zeilen van een onderneming (Lewy, 1993), door ons in het vervolg aangeduid met kritieke stuurvariabelen (ksv-en). Andere termen die hiervoor in de literatuur worden gebruikt zijn: early warning indicators, key result factors, prestatie-indicatoren of -maatstaven en pulse points. Voor dezelfde ksf-en kunnen de ksv-en per onderneming verschillen (Sellenheim, 1991). Door informatie over ksf-en, in de vorm van ksv-en, kunnen de kansen en bedreigingen in een vroegtijdig stadium worden gesignaleerd.

Traditioneel zijn de beheerssystemen van ondernemingen gebouwd op basis van korte-termijn financiële stuurvariabelen. De nadruk zal echter meer moeten komen liggen op het gebruik van stuurvariabelen die rekening houden met de voorsprong die een onderneming op de lange termijn op zijn concurrent(en) wil behalen (Kaplan, 1992).

Het uitsluitend gebruik maken van financiële variabelen maakt het vroegtijdig kunnen signaleren van plotselinge veranderingen in de vooruitzichten van de onderneming onmogelijk (Du Mée, 1991; Fickert, 1993). Financiële variabelen zijn immers meestal ex post in plaats van ex ante gericht. Bovendien kan aan deze variabelen niet worden afgelezen waaraan een onderneming haar succes te danken heeft. Lothian (1987) prefereert zelfs niet-financiële variabelen boven (kwantitatieve) financiële grootheden. Niet-financiële variabelen richten de aandacht meer op de operationele activiteiten, waardoor ze voor de langere termijn een beter inzicht geven in de te behalen financiële resultaten (National Associations of Accountants, 1986).

\section{Een pilot-study in de industrie}

Door het uitvoeren van een pilot-study onder 
een zestal industriële ondernemingen in Nederland hebben we getracht een beperkt aantal ksf-en en de daarvan afgeleide ksv-en op het spoor te komen. Daartoe zijn een zestal controllers en directeuren geïnterviewd. In deze vraaggesprekken werden onder andere de volgende zaken aan de orde gesteld:

a een algemeen gedeelte waarbij werd ingegaan op omgevings- en ondernemingskenmerken:

b het identificeren van de ksf-en. Hierbij werd gebruik gemaakt van een stapsgewijze aanpak, gebaseerd op de methodes van Van Snellenberg (1992a) en Ward (1990). De waarde van deze stapsgewijze methode ligt vooral in het systematisch nadenken over de samenhang tussen ksf-en en bedrijfsprocessen;

c hel achterhalen van de door de onderneming gebruikte ksv-en.

\section{I Gegevens empirisch onderzoek}

Het empirisch onderzoek is verricht bij een zestal ondernemingen, te weten:

- een kleine onderneming in de machine-industrie. Deze onderneming heeft 25 werknemers in dienst, terwijl de netto-omzet $f 8$ miljoen bedraagt;
- vier middelgrote ondernemingen verdeeld over de bedrijfsklassen chemische industrie, metaalproduktenindustrie, elektrotechnische industrie en transportmiddelenindustrie. Deze vier ondernemingen beschikken over een personeelsbestand variërend van 30 tot 100 werknemers en een netto-omzet variërend van rond de $f 10$ miljoen tot een kleine $f 35$ miljoen;

- een grote onderneming in de elektrotechnische industrie die wereldwijd werkgelegenheid biedt aan 9.000 werknemers en daarmee een nettoomzet van ruim $f 3$ miljard realiseert.

\subsection{Overzicht ksf-en}

Door de aan het onderzoek deelnemende ondernemingen zijn in totaal vijftien verschillende factoren als 'kritiek' aangemerkt; het aantal geformuleerde ksf-en per onderneming varieert van minimaal vier tot maximaal zeven. In Tabel 1 is een overzicht opgenomen van de per geïnterviewde onderneming genoemde ksf-en.

In het vervolg van deze paragraaf worden de door twee of meer van de geïnterviewde ondernemingen genoemde ksf-en besproken.

Tabel 1: Overzicht kritieke succesfaktoren per onderneming

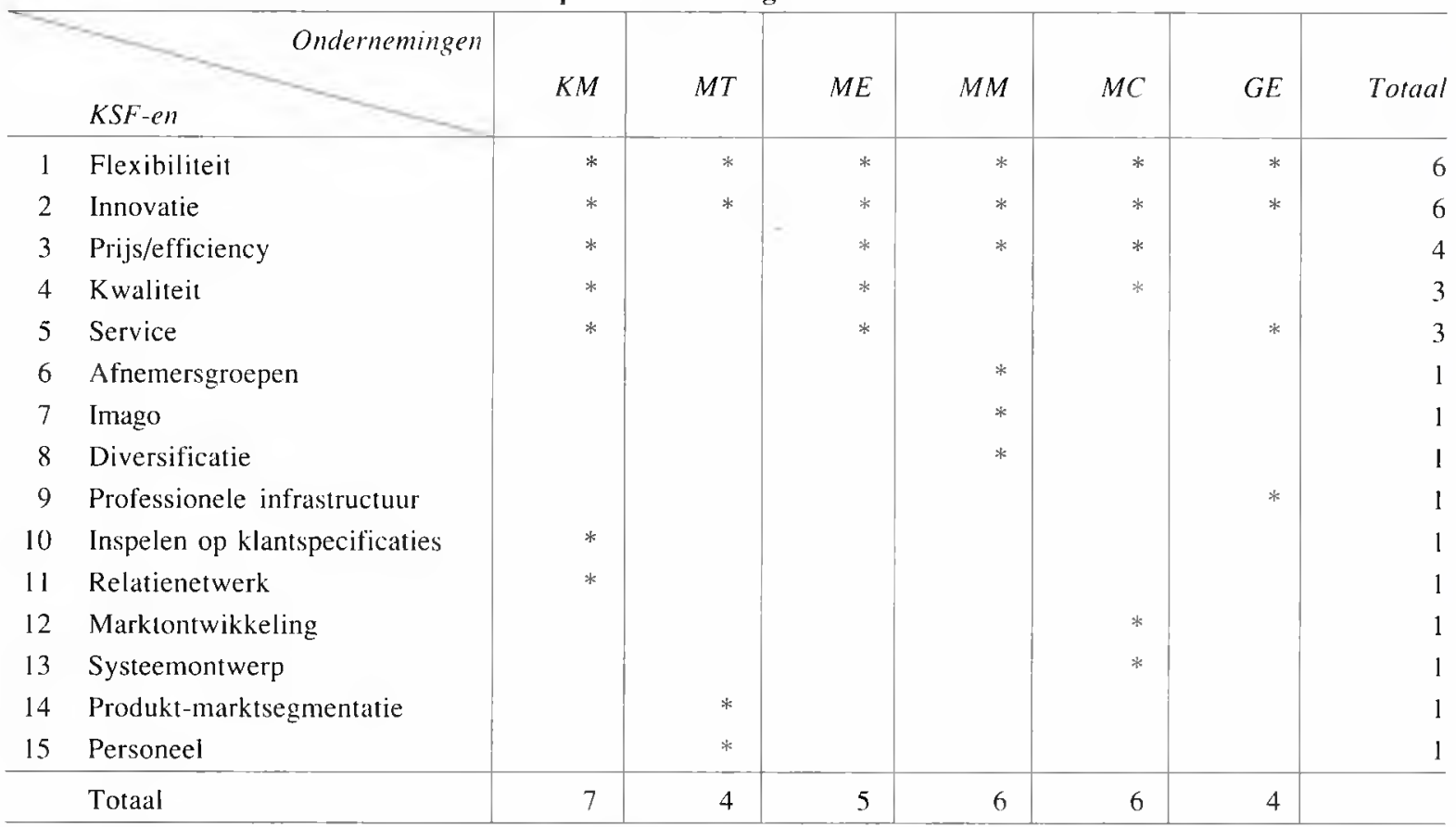

Legenda: $\mathrm{KM}=$ Kleine onderneming in de machine-industrie; $\mathrm{MT}=$ Middelgrote onderneming in de transportmiddelenindustrie; $\mathrm{ME}=$ Middelgrote onderneming in de elektrotechnische industrie; $\mathrm{MM}=$ Middelgrote onderneming in de metaalproduktenindustrie: $\mathrm{MC}=$ Middelgrote onderneming in de chemische industrie; $\mathrm{GE}=$ Grote onderneming in de elektrotechnische industrie 


\section{PRIJS/EFFICIENCY}

De markt voor standaardprodukten is er én van sterke prijsconcurrentie: de markı dicteert grotendeels de prijs van de produkten. Om de (winst)marges op een acceptabel niveau te handhaven of zelfs te vergroten. moet naar een zo laag mogelijke kostprijs worden gestreefd. Bij de kostenbcheersing spelen twee aspecten een belangrijke rol: (a) schaalgrootte en (b) inkoopkosten.

\section{Ad a:}

Een bepaalde produktie-omvang is noodzakelijk voor het behalen van schaalvoordelen. Wanneer de vaste hosten overheersen zal een zo volledig mogelijke benutting van de produktiecapaciteit gewenst zijn. Het onbeperkt nastreven van effitiency door schalalvergroting kan echter tot problemen leiden. met name op het gebied van llexibiliteit en beheersbaarheid. Uitbreiding van de produktie-omvang is daarom aan grenzen gebonden.

\section{Ad b:}

De inkoopwaarde van de goederen vormen in een aantal gevallen een relatief groot bestanddeel van de kosiprijs. Beheersing en verlaging van de inkoopwaarde is dan ook noodzaak in het streven naar een zo laag mogelijke kostprijs. De inkoopprocedure kan hierbij kritisch geacht worden: te duur inkopen leidt onherroepelijk tol (fors) margeverlies.

Prijs/efficiency speelt een minder dominante rol bij de ont wikkeling en produktie van niet standaardprodukten (specialties), aangezien de verkoopprijs voor deze produkten binnen een zekere bandbreedte kan worden vastgesteld. Deze bandbreedte is het gevolg van produktdifferentialtie in brede zin. bijvoorbeeld kwaliteit. leversnelheid, maatwerk, technologie en scrvice.

Door vier van de zes ondernemingen wordt prijs/efficiency als cen ksf aangemerkt. De twee andere ondernemingen beschouwen deze factor als een (mogelijk) toekomstige ksf.

\section{KWALITEIT}

Het kunnen leveren van kwalitatiel hoogwaardige produkten vormt een voorwatrde voor de continuïteil van industriële ondernemingen. Dalarbij blijkt hel streven naar kwaliteitsverbeteringen een belangrijke factor voor het behalen van concurrentieel voordeel. Voorop lopen met kwaliteit draagt bij aan het bewerkstelligen van een duurzane positieve relatie met de markt.

Kwaliteit behelst veelal produkt- c.q. constructiekwaliteit, waarbij het noodzakelijk is, dat men van hoog lot laag doordrongen is van hel belang van een goede kwaliteit (Total Quality Management). Binnen ondernemingen moet het omgaan met $k$ waliteit gericht zijn op kwaliteitsbeheersing in plaats van kwaliteitsinspectie: niet het opsporen van fouten, maar het voorkomen ervan dient centrial te staan.

Kwaliteil wordt door de helft van de geinterviewde ondernemingen genoemd als zijnde een ksf. voor de anderen is $\mathrm{k}$ waliteit een randvoorwatarde.

\section{FLEXIBILITEIT}

Het elkaar in versneid tempo opvolgen van produktvernieuwingen is een belangrijk wapen geworden in de concurrentiestrijd. De commerciële levensduur van produkten neemt af, terwijl de gewenste levertijden steeds korter worden. Het assortiment aan produkten neemt echter toe. Al met al vertaalt een en ander zich in een toeneming van de tijdsdruk. Het snel kunnen inspelen op veranderingen in de markt (produceren op basis van klanteisen c.4. - wensen) vormt een voorwaarde voor de continuiteil van industriële ondernemingen. De eis vanuit de markt om te komen tot verbreding van het assortiment en verkorting van de levertijd manifesteert zich voor ondernemingen als een cis van flexibiliteit. Twee aspecten spelen hierbij een belangrijke rol: (at) doorlooptijden en (b) personeel.

\section{Ad a:}

De nadruk ligt op verkorting van doorlooptijden. omdat alleen met korte doorlooptijden snel op wijzigingen in de markt kan worden gereageerd. De noodzaak 10 het versneld invoeren van technologische innovaties legt een druk op het verhogen van de flexibiliteit (zie INNOVATIE). Naast verkorting van doorlooptijden in de primaire (operationele) processen is ook reductie van ontwikkeldoorlooptijden (efficiënt ontwerpen) een essentiële factor.

\section{Ad b:}

Een positieve attitude van werknemers ten opzichte van verandering leidt tot flexibiliteit en het sneller kunnen doorvoeren van technologische innovaties. Er wordt naar gestreefd om werknemers op meerdere werkplekken in te zetten. 
Naast de know-how van werknemers is ook de wijze waarop en de mate waarin ze in staat zijn hun kennis creatief aan te wenden van belang.

Voor alle zes geïnterviewde ondernemingen manifesteert flexibiliteit zich als een ksf.

\section{INNOVATIE}

Het vermogen om snel technologische vernieuwingen toe te passen in produkten en processen is voor alle industriële ondernemingen een belangrijk middel om zich van de concurrentie te onderscheiden. Technologische vernieuwing draagt niet enkel bij tot meer flexibiliteit van ondernemingen, maar vormt mede een oorzaak van de vereiste, hogere flexibiliteit van ondernemingen. Zonder een grotere flexibiliteit is het vermogen nieuwe technologieën snel in te voeren beperkt. Naast verbetering van de flexibiliteit kan technologische innovatie leiden tot lagere kosten (verband met prijs/efficiency) en een hogere kwaliteit. In de eerste plaats heeft innovativiteit, het vernieuwen onder tijdsdruk, betrekking op de functionaliteit en de technologische vernieuwing van produkten (produktinnovatie). Tevens komt innovativiteit tot uitdrukking in het streven naar continue procesverbetering: om de hoge ontwikkelingskosten terug te kunnen verdienen moet het gehele innovatietraject, in een zo kort mogelijke tijd worden doorlopen. Verkorting van het innovatietraject behelst zowel efficiënt ontwerpen (met als doel de reductie van ontwikkeldoorlooptijden) als reductie van produktiedoorlooptijden, teneinde zo snel mogelijk een concreet produkt op de markt te kunnen brengen.

Innovatie wordt door alle aan het onderzoek deelnemende ondernemingen als een ksf bestempeld.

\section{SERVICE}

Service is vooral een strategische factor in de negentiger jaren. Door het aanbieden en naar tevredenheid uitvoeren van klantgerichte after sales service-activiteiten kan een partnership met de klant opgebouwd worden, waardoor ondernemingen zich ten opzichte van concurrenten kunnen onderscheiden (en aldus een duurzame positieve relatie met de markt kunnen opbouwen). Met name bij technisch gecompliceerde produkten is het noodzakelijk om aanvullende service-activiteiten te bieden. Service-activiteiten zijn gericht op het onderhouden van de functionaliteit en het garanderen van een probleemloos functioneren van de geleverde produkten. Te denken valt daarbij aan installatie, trainingen, preventief onderhoud, uitvoeren van reparaties, verhelpen van storingen en dergelijke.

Door drie van de zes geïnterviewde ondernemingen wordt after sales service als ksf aangemerkt. De drie andere ondernemingen beschouwen deze factor als een randvoorwaarde.

De hiervoor niet besproken, maar wel genoemde ksf-en betreffen ondernemingsspecifieke factoren (zie bijlage). Het "inspelen op klantspecificaties" en het "systeemontwerp" zijn als ksf-en nauw gerelateerd aan de factor flexibiliteit. Beide factoren kenmerken zich in essentie door het (vrijwel) volledig kunnen inspelen op klanteisen en wensen, wat tot uitdrukking komt in de levering van produkten en systemen op basis van klantspecificaties (van kleine aanpassingen tot compleet nieuwe produkten en systemen). Ook de factor "produkt-marktsegmentatie" heeft duidelijke raakvlakken met flexibiliteit als ksf: de opdeling van een onderneming in zelfstandige eenheden zorgt voor grotere commerciële slagvalardigheid, waarbij de autonome werkmaatschappijen snel kunnen inspelen op ontwikkelingen in de markt. Ten slotte, "diversificatie" is mede bepalend voor het bereiken van schaalgrootte en kan gekoppeld worden aan de hiervoor besproken factor prijs/ efficiency.

Vaststelling van ksf-en en ksv-en is weliswaar essentieel, maar bepalend voor het succes van ondernemingen is het tijdig ondernemen van de juiste actie. In die zin kan kwaliteit van het management als een overkoepelende ksf worden beschouwd. De ondernemingsleiding moet zich bewust zijn van de dynamiek betreffende de ksf-en in de tijd. De ondernemingsleiding zal voortdurend alert moeten zijn op zowel interne als externe veranderingen en hierop adequaat moeten reageren door middel van evaluatie en aanpassing. Binnen de onderzochte ondernemingen is evaluatie en aanpassing van ksf-en veelal (impliciet) eens per jaar aan de orde als onderdeel van besprekingen over het strategisch plan.

\section{Managementinformatie op basis van ksv-en}

Alle onderzochte ondernemingen zijn in staat gebleken om de voor hen geldende ksf-en te 
Tabel 2: Ksf-en en ksv-en, door twee of meerdere ondernemingen genoemd

\begin{tabular}{|c|c|c|}
\hline $\begin{array}{l}\text { Aantal } \\
\text { ondernemingen }\end{array}$ & $\begin{array}{l}\text { Kritieke } \\
\text { sucresfartor }\end{array}$ & $\begin{array}{l}\text { Kritieke } \\
\text { stmurariabelen }\end{array}$ \\
\hline 6 & Flexibiliteit & $\begin{array}{l}\text { - multi-inzetbaarheid werknemers } \\
\text { - ziekteverzum. verloop personeel } \\
\text { - voorraadniveau } \\
\text { - \% alantal orders op tijd } \\
\text { - \% omzel in specialties } \\
\text { - ontwikkeldoorlooptijden } \\
\text { - produktiedoorlooptijden } \\
\text { - leverbetrouwbaarheid van leveranciers } \\
\text { - breedte van alssortiment. aantal produkten per soort } \\
\text { - \% aantal niet tijdig geleverde offerte-aanvragen } \\
\text { - verhouding standaird vs. afwijkende produkten }\end{array}$ \\
\hline 6 & Innovalle & $\begin{array}{l}\text { - \% alantal nieuwe produkten van totatal aantal produkten } \\
\text { - aandeel nieuwe produkten in de omzet } \\
\text { - R \& D uitgaven in \% van de omzet } \\
\text { - aantal ontwikkeluren (planning vs. realisatie) } \\
\text { - produktspecificatic eigen produkten vs. produkten van concurrenten } \\
\text { - evaluatie klantenwensen } \\
\text { - vernieuwingskracht in verhouding tot de concurrentie } \\
\text { - groei van het marktaindeel en de omzet (planning vs. realisatie) } \\
\text { - aantal patenten en -aanvrigen } \\
\text { - produktefficiency in vergelijking met de concurrentic } \\
\text { - wairdering van derden toegekend aan concrete produktoplossingen }\end{array}$ \\
\hline 4 & Prijs/efficiency & $\begin{array}{l}\text { - toegevoegde walarde per werknemer } \\
\text { - vaste kosten in \% van de onzet } \\
\text { - inkoopkosten in \% van de omzel } \\
\text { - directe materialalkosten in \% van de totale directe kosten } \\
\text { - verhouding directe kosten vs. indirecte kosten } \\
\text { - aantal afgekeurde inkooporders } \\
\text { - gemiddelde omzet per produktionedewerker } \\
\text { - vergelijking van leveranciers }\end{array}$ \\
\hline 3 & Kwaliteit & $\begin{array}{l}\text { - garantiekosten per maand } \\
\text { - uitval \% } \\
\text { - aantal klachten van klanten } \\
\text { - \% aantal produkten dat aan specificatie voldoet na eindcontrole } \\
\text { - kwalitalieve informatie over de alard en inhoud van service- en } \\
\text { reparatiewerkatamheden } \\
\text { - \% atantal afgekeurde of gecorrigeerde tekeningen }\end{array}$ \\
\hline 3 & Service & $\begin{array}{l}\text { - aantal klachten over service } \\
\text { - \% atuntal op tijd geleverde onderdelen } \\
\text { - doorlooptijden service en reparaties } \\
\text { - atintal service-oproepen } \\
\text { - aantal reparaties die in één keer de oorzalak van problemen wegnemen } \\
\text { in \% van totalal } \\
\text { - evaluatie van klanteneisen en -klachten } \\
\text { - aantal benodigde uren en onderdelen per service-oproep }\end{array}$ \\
\hline
\end{tabular}


formuleren en te vertalen naar daarvan afgeleide ksv-en (zie de bijlage achteraan het artikel). Formele vastlegging en rapportage over ksv-en is echter nog geen gemeengoed, maar vindt in de door ons geïnterviewde ondernemingen alleen plaats in de middelgrote ondernemingen. In de kleinste en grootste onderneming wordt hoofdzakelijk nog met financiële gegevens gewerkt. Als uit de financiële cijfers blijkt dat de ondernemingsprestaties te wensen over laten, is het zaak meer gedetailleerde informatie te achterhalen om de oorzaken van de tegenvallende prestaties aan het licht te brengen. Het beleid van de grootste onderneming is er wel op gericht om in de toekomst meer niet-financiële kengetallen en indicatoren te gaan hanteren. In Tabel 2 zijn de ksf-en met de daaraan gekoppelde ksv-en opgenomen die door twee of meerdere ondernemingen zijn genoemd.

In de middelgrote ondernemingen wordt naast de rapportage over ksv-en veel waarde gehecht aan informele contacten bij het besturen van de onderneming. Aan direct toezicht op de bedrijfsvloer blijkt hier minder behoefte te zijn. In de kleinere onderneming wordt vooral gestuurd op basis van ervaring, kennis en intuïtie. Direct toezicht, informele contacten en formeel overleg worden hier van meer belang geacht dan het sturen op basis van ksv-en. Desalniettemin baseert de ondernemer/eigenaar zich bij de besturing en beheersing van zijn onderneming op indirecte en ad hoc informatie over ksf-en, ook al zijn deze factoren niet expliciet omschreven en vastgelegd.

In de meeste bedrijven wordt over de ksv-en periodiek gerapporteerd, maar eventueel ook ad hoc naar aanleiding van intuïtief of informeel gesignaleerde afwijkingen en ontwikkelingen. Opvallend is dat slechts bij één (middelgrote) onderneming normen en richtwaarden voor ksv-en zijn vastgelegd. Bij de overige geïnterviewde ondernemingen ontbreken formeel vastgelegde normen en richtwaarden vrijwel geheel; gestreefd wordt naar continue procesverbetering. Uiteindelijk zal dit streven moeten leiden tot betere ondernemingsprestaties. In een enkel geval worden ondernemingsprestaties geëvalueerd aan de hand van interne en externe vergelijkingen (benchmarking).

Selectie en aanpassing van ksv-en voltrekt zich in het merendeel van de onderzochte ondernemingen als een continu maar weinig gestructureerd proces.

\section{Evaluatie van de uitkomsten van de pilot-study in de industrie}

In het begin van dit artikel hebben we een beknopt overzicht gegeven van de bestaande literatuur over ksf-en en ksv-en. Vervolgens hebben we de resultaten van de pilot-study besproken. Nu zullen we de conclusies van onze pilot-study in de industrie toetsen aan hetgeen we in de literatuur hebben gevonden. Vanwege de overzichtelijkheid worden de ksf-en en ksv-en afzonderlijk besproken. Enige voorzichtigheid bij de generalisatie van de gevonden uitkomsten is op zijn plaats vanwege het beperkt aantal (6) onderzochte ondernemingen.

\subsection{Relatie tussen strategie en kritieke succesfactoren}

Uit ons onderzoek blijkt, dat ondernemingen zich bij het bepalen van hun strategie richten op factoren die naar hun mening van essentieel belang zijn voor het succesvol voortbestaan van de onderneming. De keuze van strategieën is veelal gebaseerd op een analyse van de wijze waarop een onderneming haar (concurrentie)positie in de markt te gelde kan maken. Op basis van deze analyse worden de ksf-en van de onderneming bepaald. Pas daarna wordt gekeken welke strategie moet worden gevolgd om de gestelde. doelen te bereiken. Deze bevinding komt overeen met hetgeen we eerder al stelden, namelijk dat ksfen bepalend zijn voor de strategie en niet omgekeerd.

\subsection{Universele ksf-en}

Opvallend is de overeenkomst tussen de ksf-en die we bij twee of meer geïnterviewde ondernemingen hebben aangetroffen en de resultaten van een studie van Bolwijn en Kumpe (1991). In deze studie worden efficiency, kwaliteit, flexibiliteit en innovativiteit genoemd als markteisen waar ondernemingen in deze tijd gelijktijdig aan moeten voldoen. Volgens Ballemans (1991) kunnen markteisen als ksf-en beschouwd worden. Los van de studie van Bolwijn en Kumpe (1991) zijn op basis van internationaal onderzoek de volgende ksf-en geformuleerd (Maisel, 1992):

- winstgevendheid;

- kwaliteit;

- flexibiliteit; 
- snelheid van reageren op wensen van de klant;

- innovatie.

Winstgevendlheid hangt direct samen mel prijs/ efficiency. alangezien de kostprijs van een produkt in belangrijke mate bepalend is voor de uiteindelijke winstmarge. Snelheid van reageren op wensen van de klant is als ksf nauw gerelateerd alan de cerder genoemde factor flexibiliteit. Volgens Humble (1987) zou aan bovenstaand rijlje voor de negentiger jaren nog de factor "service" moeten worden toegevoegd. Voor cen afwijkende mening wat betreft de factor " $k$ waliteit" wordt verwezen naar Fritz (1995).

Als we de studie van Bolwijn en Kumpe (1991), het internationaal onderzoek van Maisel (1992) en de uilkomsten van onze pilot-study met elkalar vergelijken, dan blijkt dat in onze pilotstudy slechts twee kst-en (llexibiliteit en innovatie) door alle geïnterviewde ondernemingen worden genoemd. De ksl " prijs/efficiency" wordt door vier van de zes onderzochte ondernemingen genoemd en "kwaliteit" en "service" worden door de helli van de onder\%oekspopulatie als ksf-en aangemerkt. Deze constatering leidt tot de voorzichtige conclusie, dat niet alle door Bolwijn en Kumpe. Humble en Maisel genoemde ksf-en universele geldigheid bezitten voor alle industriële ondernemingen. De conclusie word nog versterkı door het feit. dat de universele ksf-en "flexibili1eit" en "innovatie" veel verschillende dimensies hevatten.

\subsection{Ondernemingsspecificke ksf-en}

Vijf van de zes ondernemingen uit onze pilor study blijken over een aantal ondernemingsspecilieke ksf-en te beschikken (zie de bijlage). Deze ksf-en vertonen sterke overeenkomsten met zowel interne sterkten als interne zwakten van ondernemingen. De als interne zwakten aan te merken ondernemingsspecifieke ksf-en onderscheiden zich door hun aard van de andere (ondememingsspecifieke) ksf-en. Als er sprake is van een interne zwakte heefi de onderneming een duidelijke achterstand ten opzichte van de concurrentie, of kom de onderneming in relatie tol de markt onvoldoende uit de verf. Deze ksf-en zullen alangepast en verbeterd moeten worden met het oog op de continuïteit van de betrokken ondernemingen en zijn in dic zin als kritiek te beschouwen.
Samenvattend kunnen we op grond van literatuurstudic en (in mindere mate) op basis van onze bevindingen uit de pilot-study een tweetal niveaus van ksf-en onderscheiden, universele ksf-en en ondernemingsspecifieke ksf-en.

\subsection{Onderscheidend rermogen op basis ran universele kisf-en}

De vraag dringt zich op of universele ksf-en industriële ondernemingen wel de mogelijkheid bieden om zich van de concurrentie te onderscheiden, zodiat een duurzame positieve relatie met de markı kan worden opgebouwd. Naar onze mening is dat zeker hel geval en staan daartoe een tweetal wegen open, namelijk:

a) de nadere invulling van universele ksf-en.

watardoor ondernemingen zich op basis van

dezelide $k s f-e n$ toch ten opzichte van elkalar

kunnen onderscheiden:

b) de kwaliteit van het management.

Ad a:

Athankelijk van de kenmerken van een onderneming en haar omgeving zal de nadere invulling van ksf-en tussen ondernemingen verschillen. Als voorbeeld van ondernemingskenmerken kunnen worden genoemd: schaalgrootte (Lewy. 1992) en de complexiteit van het produktieproces (Woodward. 1965). Voorbeelden van omgevingskenmerken zijn: omgevingsdynamiek (Gordon en Miller, 1976), relatieve machtsverdeling binnen de branche (Porter, 1979) en transactiecomplexitcit (Vasconsellos. 1989). Ter illustratie worden hieronder een tweetal voorbeclden gegeven.

Een cerste voorbeeld is de ksf "flexibiliteit" in relatie tot de schaalgrootle van een onderneming. Voor grote ondernemingen manifesteent flexibilileit zich mel name in het begrip snelheid, het zo snel mogelijk omzetten van ideeën in een breed assortiment marktklare, min of meer standaardproduklen. Dil gegeven is van levensbelang, alangezien hel succes van grote ondernemingen in belangrijke mate afhankelijk is vall de snelheid waarmee technologische vernieuwingen in produkten doorgevoerd kunnen worden. Om de hoge ontwikkelingskosten terug te kunnen verdienen, moeten deze ondernemingen hel gehele ontwikkelings- en produktieproces in zo kort mogelijke tijd doorlopen. Voor kleine en middelgrote ondernemingen manifesteert flexibiliteit zich vooral in de produktie van meer klantspecifieke produkten 
(flexibiliteit in de zin van inspelen op klantspecificaties, waarbij snelheid een randvoorwaarde is).

Een tweede voorbeeld afgeleid uit de pilot study is de invloed van de complexiteit van het produktieproces op de genoemde ksf-en. Met enige voorzichtigheid kunnen we stellen dat ondernemingen met een eenvoudig produktieproces, levertijd en -betrouwbaarheid als relatief belangrijke ksf-en zien. Naarmate het produktieproces meer complex wordt, verschuift de aandacht naar factoren als service, breedte van het assortiment en innovatief vermogen.

\section{Ad $b$ :}

Niet alleen de ksf-en zelf zijn bepalend voor een onderscheidend vermogen ten opzichte van de concurrentie. maar ook de wijze waarop de ondernemingsleiding deze ksf-en in haar beleid weet te incorporeren (Ballemans, 1991). Wij noemen in dit verband twee uitgangspunten die een basis scheppen voor het behalen van concurrentiële voordelen: (a) de snelheid waarmee en de mate waarin ondernemingen universele $\mathrm{ksf}$-en als een uitdaging zien en in staat zijn deze ksf-en naar passende ondernemingsstrategieën te vertalen, en (b) de keuze van ksv-en en de invulling en uitvoering van concreet ondernemingsbeleid op basis van ksf-en en ksv-en. Het tijdig ondernemen van de juiste actie op basis van ksf-en en ksv-en vormt een essentieel onderdeel voor hel succes van ondernemingen. Kortom, de kwaliteit van het management is een basis voor het bewerkstelligen van een onderscheidend vermogen ten opzichte van de concurrentie en het opbouwen van een duurzame positieve relatie met de markt. Kwaliteit van het management kan in feite als overkoepelende succesfactor worden beschouwd.

Het is echter onvoldoende dat uitsluitend de ondernemingsleiding zich sterk makt voor het ontwikkelen van ksf-en. Om de plannen in de onderneming ingevoerd te krijgen, moet iedereen in de onderneming doordrongen zijn van het feit dat het werken met ksf-en en ksv-en de continuïteit ten goede komt. Kortom: de motivatie in de onderneming dient zodanig te zijn dat de onderneming in staat is op het gekozen moment de noodzakelijke krachten gebundeld op het gekozen doel te richten (Ogilvie en Piëst, 1988).

\subsection{Kriticke stuurvariabelen}

Uit onze studie blijkt dat ksv-en zowel finan- ciële als niet-financiële kengetallen en indicatoren betreffen. Naast kwantificeerbare (niet-fïnanciële) ksv-en hanteren ondernemingen in hun interne rapporteringssysteem eveneens kwalitatieve informatie. In het empirisch onderzoek werden vier keer zoveel niet-financiële als financiële kengetallen en indicatoren als ksv-en aangemerkt. Voor een volledig overzicht van de ksv-en wordt verwezen naar de bijlage.

Athankelijk van de geformuleerde ksf-en zullen ksv-en van onderneming tot onderneming verschillen (Sellenheim. 1991). Deze bewering wordt door onze onderzoeksgegevens bevestigd: verschillende ksf-en worden door middel van uiteenlopende ksv-en gemeten en bewakt (zie bijlage). Wanneer ondernemingen dezelfde ksf-en gebruiken. dan betekent dat nog niet dat deze ondernemingen ook dezelfde ksv-en hanteren. Elke individuele onderneming blijkt met ksv-en te werken die zijn toegesneden op de eigen specifieke activiteiten en het commercieel profiel van de onderneming (zie eveneens Lewy, 1992).

\subsection{Veranderlijkheid ran ksf-en en ksv-en}

Het ontwikkelen van ksf-en en de daarvan afgeleide ksv-en is een dynamisch proces. Door de snelle veranderingen in de markı. maar ook binnen de onderneming, kunnen de factoren die van doorslaggevend belang zijn voor het succes van ondernemingen in de tijd gezien wijzigen. Vermeldenswaard is, dat volgens een aantal geïnterviewde directeuren/controllers de universele ksf-en zich in de tijd gezien kenmerken door stabiliteit. Hoewel nieuwe universele ksf-en in de tijd gezien relevant zullen worden, moeten ondernemingen ook aan de reeds bestaande universele ksf-en blijven voldoen. Ter vergelijking: Bolwijn en Kumpe (1991) stellen, dat ondernemingen vanuit de markt gezien in deze tijd gelijktijdig moeten voldoen aan de eisen efficiency, kwaliteit, flexibiliteit en innovativiteit.

Als gevolg van verschuivingen in ksf-en zullen ook de gehanteerde ksv-en aangepast moeten worden. Ksv-en zijn immers van ksf-en afgeleid en verschillen afhankelijk van de geformuleerde ksf-en. De ondememingsleiding moet er zich dan ook steeds van bewust zijn dat de ksf-en en ksv-en kunnen veranderen. Het is derhalve raadzaam om minstens éénmaal per jaar een "ksf/ksv-ronde" te organiseren. met als doel evaluatie en eventuele 
aampassing van ksf-en en de daarvan afgeleide ksv-en (De Waal en Buluhuis, 1993).

\section{Praktische gebruikswalarde}

Voor grote ondernemingen kan het werken met kst-en en ksv-en helpen bij hel beperken van de informatiestroom in de onderneming. Door de verslaglegging toe te spitsen op de meest kritieke elementen, de van de ksf-en algeleide stuurvariabelen (de ksv-en). kan dil doel worden bereikt. Managementinformatie op basis van ksv-en kan een tijdsbesparing voor het management betekenen. omdat de interne berichtgeving tot de stuurvariabelen beperkt kan blijven (Hofenk. 1993). Voor kleine ondernemingen liggen de voordelen op een ander vlak. Van Snellenberg (1992a) haalt een praktijkvoorbeeld aan walirmee hij illustreen dat vooral bij grociende familie-ondernemingen nal het terugtreden of wegvallen van de directeur/ eigenaar vaak grote behoefte alan stuurinformatie onlstilat. Het "Fingerspitzen-gefühl" van de oorspronkelijke directeur/eigenalar. dat gevoed werd door een totale verwevenheid met de onderneming, verdwijnt met de wisseling van de wacht. Bij kleine ondernemingen kan door analyse van kst-en een aantal zaken die nu alleen intuïtief bij de directeur/eigenalar leven expliciet worden gemalakı, hetgeen de continuïteit ten goede komt. De rapportage wordt dan immers gerich op voor de onderneming van levensbelang zijnde stuurvariabclen. de ksv-en.

Ter illustratie is in onderstaand kader een praktijkvoorbeeld opgenomen. afkomstig van een onderneming die zich toelegt op de ontwikkeling. produktie en verkoop van container handling equipment.

Do markt roor standaurdprodukten kenmerkt sich an de verkoopzijde door een sterke prijsconcurrentice, waurbij de markt grotendeels de rerkoopprijzen voor deze standaardprodukten dicteert. Vanuit de klant gezien (extem) rormt de verkoopprijs een belangrijk atmkoopcriterium en is datadoor cen kritieke succesfactor roor de onderneming.

Om nu de winstmarges van standaardprodukten op een acceptabel nivean te handhaven (of te vergroten), moet nat zo laag mogelijke kostprijzen gestreefd worden. Intern is hierbij de inkoopprijs ran de benodigde materialen ran doorslaggevend belang. De hoogle van de inkoopprijs is bepalend voor het realiseren ran voldoende rendement bij e'en door de markt gedicteerde verkoopprijs. Een fractie te daur inkopen zal leiden tot cen fors margeverlies. De ondernemingsleiding wordt hierover geinformeerd door het gebruik ran een kritieke stumrariabele (ks'). Als kis hanteert de onderneming in dit geval de inkoopquote (gedefinieerd als: inkoopprijs/ omze't * $100 \%$ ).

De kist "inkoopquote" geeft ee'l vroegtijdig signaal over de ontwikkeling van de winstmarge. De ondernemingsleiding kan dan zo nodig corrigerende maatregelen treffen.

\section{Samenvatting en conclusies ${ }^{3}$}

De term kritieke succesfactoren ( $k$ sf-en) blijkt dikwijls te leiden tol een Babylonische spraakverwarring. omdat meestal niet duidelijk is aangegeven wat ermee wordt bedoeld. Wij omschrijven ksf-en als: "De factoren op hasis waaran e'en onderneming zich ten opzichte van de concurrentie kan onderscheiden om aldus een durtrzame positieve relatie met de markt op te houwen". Uit het oogpunt van menselijk bevattingsvermogen, complexiteit en kostenoverwegingen kunnen slechts een beperkt aantal succesfactoren worden gehanteerd. De meeste publikaties komen uit op zes. Zijn de succesfactoren eenmaial bepaald, dan moeten deze worden bewaakt met behulp van kengetallen en indicatoren, de kritieke stuurvariabelen (ksv-en). Financiële kengetallen en indicatoren geven slechts informatie over de korte-termijnprestaties en zijn meestal ex post in plaats van ex ante gericht. Het aan de financiële stuurvariabelen toevoegen van meer niet-financiële informatie is dan ook noodzakelijk.

Uit een door ons uitgevoerde pilot-study onder een zestal industriële ondernemingen in respectievelijk de chemische industrie, metalalproduktenindustrie, machine-industrie, elektrotechnische industrie en de transportmiddelenindustrie komen een vijftiental ksf-en naar voren. Het meest werden genoemd: flexibiliteit, innovatie, prijs/ efficiency, kwaliteit en service. Het ontwikkelen van $k s f-e n$ en ksv-en blijkt, als gevolg van ontwikkelingen in de markt en veranderingen in de onderneming, een dynamisch proces te zijn. Formele verslaglegging van ksf-en. door middel van ksv-en. is nog steeds geen gemeengoed. Er 
wordt nog hoofdzakelijk met financiële gegevens gewerkt. Het bepalen van de ksf-en blijkt vooraf te gaan aan het vaststellen van de te volgen strategie. Op grond van onze bevindingen kunnen we een tweetal niveaus van ksf-en onderscheiden: universele ksf-en en ondernemingsspecifieke ksfen. Het tijdig ondernemen van de juiste actie op basis van ksf-en en ksv-en is essentieel voor het succesvol voortbestaan van ondernemingen. De kwaliteit van het management is hierbij een dusdanig belangrijke factor, dat deze als een overkoepelende succesfactor kan worden beschouwd.

Verder onderzoek kan zich richten op de vraag of wellicht voor verschillende groepen van ondernemingen onderling dezelfde ksf-en gelden.

Hiermee zou een derde niveau van ksf-en te identificeren zijn, namelijk ksf-en behorende bij een bepaald cluster van ondernemingen.

BIJLAGE: Volledig overzicht ksf-en en ksv-en uit de pilot-study

\begin{tabular}{lll}
\hline $\begin{array}{l}\text { Aantal } \\
\text { genoemd }\end{array}$ & Kritieke & Kritieke \\
succesfactor & stuurvariabelen \\
\hline 6 & Flexibiliteit & multi-inzetbaarheid werknemers \\
& - ziekteverzuim, verloop personeel \\
& - voorraadniveau \\
& $-\%$ aantal orders op tijd \\
& $-\%$ omzet in specialties \\
& - ontwikkeldoorlooptijden \\
& - produktiedoorlooptijden \\
& - leverbetrouwbaarheid van leveranciers \\
& - breedte van assortiment. aantal produkten per soort \\
& $-\%$ aantal niet tijdig geleverde offerte-aanvragen \\
& - verhouding standaard vs. afwijkende produkten \\
&
\end{tabular}

6

Innovatie
- \% aantal nieuwe produkten van totaal aantal produkten

- aandeel nieuwe produkten in de omzet

- R \& D uitgaven in \% van de omzet

- aantal ontwikkeluren (planning vs. realisatie)

- produktspecificatie eigen produkten vs. produkten van concurrenten

- evaluatie klantenwensen

- vernieuwingskracht in verhouding tot de concurrentie

- groei van het marktaandeel en de omzet (planning vs. realisatie)

- aantal patenten en -aanvragen

- produktefficiency in vergelijking met de concurrentie

- waardering van derden toegekend aan concrete produktoplossingen

\section{4}

Prijs/efficiency

- toegevoegde waarde per werknemer

- vaste kosten in \% van de omzet

- inkoopkosten in \% van de omzet

- directe materiaalkosten in \% van de totale directe kosten

- verhouding directe kosten vs. indirecte kosten

- aantal afgekeurde inkooporders

- gemiddelde omzet per produktiemedewerker

- vergelijking van leveranciers

$\begin{array}{ll}3 \quad \text { Kwaliteit } & - \text { garantiekosten per maand } \\ & - \text { uitval } \% \\ & - \text { aantal klachten van klanten }\end{array}$


- \% aantal produkten dat aan specificatie voldoet na eindcontrole

- kwalitatieve informatie over de aard en inhoud van service- en reparatiewerkzaamheden

- \% aantal afgekeurde of gecorrigeerde tekeningen

\begin{tabular}{|c|c|c|}
\hline 3 & Service & $\begin{array}{l}\text { - aantal klachten over service } \\
\text { - \% aantal op tijd geleverde onderdelen } \\
\text { - doorlooptijden service en reparaties } \\
\text { - aantal service-oproepen } \\
\text { - aantal reparaties die in één keer de oorzaak van problemen wegnemen } \\
\text { in \% van totaal } \\
\text { - evaluatie van klanteneisen en -klachten } \\
\text { - aantal benodigde uren en onderdelen per service-oproep }\end{array}$ \\
\hline 1 & Afnemersgroepen & $\begin{array}{l}\text { - gemiddeld omzet bij de verschillende afnemersgroepen } \\
\text { - eigen aandeel in omzet verschillende afnemersgroepen } \\
\text { - ontwikkelingen in aard en aantal afnemersgroepen }\end{array}$ \\
\hline 1 & Imago & $\begin{array}{l}\text { - aantal showroomplaatsen } \\
\text { - groei eigen omzet in \% van groei omzet totale markt } \\
\text { - merkenbekendheid (NIPO-meting) } \\
\text { - marktaandeel }\end{array}$ \\
\hline 1 & Diversificatie & $\begin{array}{l}\text { - rendementsverwachtingen } \\
\text { - marktgroei(verwachtingen) } \\
\text { - aard en aantal huidige en potentiële concurrenten }\end{array}$ \\
\hline 1 & $\begin{array}{l}\text { Professionele } \\
\text { infrastructuur }\end{array}$ & $\begin{array}{l}\text { - evaluatie tevredenheid service- en ontwikkelingspersoneel } \\
\text { - aanwezige expert- en testsystemen } \\
\text { - aantal beschikbare trainingsprogramma's } \\
\text { - leverbetrouwbaarheid onderdelen voor service en reparatie }\end{array}$ \\
\hline 1 & $\begin{array}{l}\text { Inspelen op } \\
\text { klantenspecificaties }\end{array}$ & $\begin{array}{l}\text { - aantal engineeringsuren per offerte } \\
\text { - aantal engineeringsuren per order } \\
\text { - aantal niet in behandeling genomen aanvragen } \\
\text { - kwalitatieve informatie tot op welke hoogte ingespeeld kan worden op } \\
\text { klantspecifieke produkteisen en -behoeften }\end{array}$ \\
\hline 1 & Relatienetwerk & $\begin{array}{l}\text { - kwalitatieve informatie over ontwikkelingen in alantal en achtergronden } \\
\text { van afnemers } \\
\text { - aantal nieuwe opdrachten per jaar } \\
\text { - omzetverhouding nieuwe vs. bestaande relaties }\end{array}$ \\
\hline 1 & Marktontwikkeling & $\begin{array}{l}\text { - aantal nieuwe relaties per jaar } \\
\text { - aantal nieuwe orders per jaar } \\
\text { - gemiddelde omzet bij verschillende afnemersgroepen }\end{array}$ \\
\hline 1 & Systeemontwerp & $\begin{array}{l}\text { - aantal niet-standaard systemen } \\
\text { - aantal orders voor standaard systemen in \% van totaal aantal orders }\end{array}$ \\
\hline 1 & $\begin{array}{l}\text { Produkt/markt- } \\
\text { segmentatie }\end{array}$ & $\begin{array}{l}\text { - aantal verschillende produktsoorten } \\
\text { - kwalitatieve informatie met betrekking tot de relatie tussen de aanvragen } \\
\text { voor produktinnovatie en de core business van de werkmaatschappij }\end{array}$ \\
\hline 1 & Personeel & $\begin{array}{l}\text { - ziekteverzuim en verloop personeel } \\
\text { - tevredenheid personeel in vergelijking met andere ondernemingen } \\
\text { - aantal calamiteiten met betrekking tot het functioneren van werknemers }\end{array}$ \\
\hline
\end{tabular}




\section{I T ERATU UR}

Anthony, R.N., J. Dearden \& N.M. Bedford, (1989), Management control systems, zesde editie, Homewood, Irwin.

Anthony, R.N., J. Dearden \& V. Govindarajan, (1992), Management control systems, zevende editie, Homewood, Irwin.

Atkinson, Anthony A., Rajiv D. Banker \& Robert S. Kaplan, (1995), Management Accounting, Prentice Hall International Editions, Englewood Cliffs, New Jersey 07632.

Ballemans, A.T.M., (1991), 'Performance measurement geëvalueerd', Maandblad voor Bedriffsadministratie en organisatie.

Bolwijn, P.T. \& T. Kumpe, (1992), Marktgericht ondernemen, Management van continü̈teit en vernieuwing, tweede editie, Assen, Van Gorcum.

Boynton, A.C. \& R.W. Zmud, (1984), 'An assessment of critical success factors', Sloan Management Review.

Bungay, S. \& M. Goold, (1991), 'Creating a strategic control system', Long Range Planning.

Daniel, D.R., (1961), 'Management Information Crisis', Harvard Business Review, September/October.

Du Mée, A.F., (1991), 'Niet financiële informatie, Kritische succesfactoren in de interne berichtgeving', In: L. Traas \& E. de With (eds.), Handboek Management Accounting, Alphen aan den Rijn, Samsom Bedrijfsinformatie, september.

Fickert, Reiner, (1993), 'Management Accounting-quo vadis?', Die Unternehmung: Schweizerische Zeitschrift für Betriebswirtschaft.

Fritz, Wolfgang, (1994), 'Die Produktqualität: Ein Schlüsselfaktor des Unternehmens erfolgs?', Zeitschrift für Betriebswirtschaft.

Gordon, L.A. \& D. Miller, (1976), 'A contingency framework for the design of accounting information systems', Accounting, Organizations and Society, 1.

Hahn, D. \& U. Krystek, (1979), 'Betriebliche und übertriebliche Frühwarnsysteme für die Industrie', Zeitschrift für betriebswirtschafts Forschung.

Hofenk, W.A., (1993), 'Wegens succes geprolongeerd', Afstudeerwerkstuk voor de sectie Kosten, Waarde en Winst van de vakgroep Bedrifseconomie, Faculteit der Economische Wetenschappen, Katholieke Universiteit Brabant, december.

Hofenk, W.A. \& M.F.C.M. Wijn, (1994), 'Kritieke Succesfactoren: Strategie en control', Ra'drs, jaargang 93/94, no.5.

Humble, J., (1987), 'Beating back the competition', Chief executive, February.

Johnson, H., (1992), Relevance regained, From top-down control to bottom-up empowerment, New York. Free Press.
Kaplan, R.S., (1992), 'Measuring manufacturing performance, A new challenge for managerial accounting research', In: C.R. Emmanuel, D.T. Otley \& K. Merchant (eds.), Readings in accounting for management control, London, Chapman \& Hall.

Keuning, D. \& D.J. Eppink, (1987), Management en organisatie, Theorie en toepassing, derde editie, Leiden, Stenfert Kroese

Kotler, P., (1991), Marketing management, Analysis, planning, implementation and control, zevende editie, Englewood Cliffs, New Yersey, Prentice-Hall.

Krijnen, H.G. \& A.W.H. Geven, (1991), 'Kritische succesfactoren, Een verwarrend en overbodig begrip in de strategische beleidstheorie', Bedrijfskunde.

Leidecker, J.K. \& A.V. Bruno, (1984),'Indentifying and using critical success factors', Long Range Planning.

Lewy, C.P., (1992), Management control regained, De financieel/economische beheersing van complexe organisaties, Een integratie van theorie en praktijk, Deventer, Kluwer Bedrijfswetenschappen.

Lewy, C.P., (1993), 'Versterkte dijkbewaking, Noodzaak bij losse delegatie', Tiidschrift Financieel Management.

Lothian, N., (1987), Measuring corporate performance, A guide to non financial indicators, London, CIMA, Occasional Paper Series.

Maisel, S., (1992), 'Performance measurement, The balanced scorecard approach', Journal of Cost Management, summer.

National Association of Accountants (NAA), (1986), 'Measuring entity performance', Management Accounting, March.

Ogilvie, R.G. \& E. Piëst, (1988), 'Kritische succesfactoren, Naar een definitie', Tiidschrift Financieel Management.

Ohmae, K., (1982). The mind of the strategist, The art of Japanese business, New York, McGraw-Hill.

Porter, M.E., (1979), 'How competitive forces shape strategy', Harvard Business Review, March/April.

Rockart, J.F., (1979), 'Chief executives define their own data needs', Harvard Business Review, March/April.

Sellenheim, M.R., (1991), 'Performance measurement', Management Accounting.

Snellenberg, H. van \& N. Dikstaal, (1992a), 'Stuur naar succes op juiste variabelen', Rendement, april.

Snellenberg, H. van \& N. Dikstaal, (1992b), 'Marktpositie dicteert stuurvariabelen', Rendement, mei.

Tjoe Nij, H.J.A. \& J.A. Bletz, (1993), 'Michael Porter: ken uw krachten en excelleer', Rendement, maart.

Vasconsellos, J.A.S. \& D.C. Hambrick, (1989), 'Key success factors, Test of a general theory in the mature industrial product sector', Strategic Management Journal, 10

Waal, A.A. de \& H. Bulthuis, (1993), 'Praktische ontwikkeling van kritische succesfactoren', Tijdschrift Financieel Management. 
Ward, B., (1990), 'Planning for profit', In: T. Lincoln (ed.), Managing information systems for profit, Chichester, John Wiley \& Sons

Wijn, M.F.C.M. W.A. Hofenk, R.W. Hoekstra \& M.B. Hengeveld, (1994), Kritische Succesfactoren aan een nadere analyse onderworpen, Research Memorandum, Faculty of Economics and Business Administration, Tilburg University, FEW 668

Woodward, J., (1965), Industrial organization, Theory and practice, Oxford, U.P.

\section{NOTEN}

1 De auteurs danken Prof. Dr. R. Bannink (KU Brabant), Prof. Dr. W.G.H. van Hulst (KU Brabant), Drs. H.G. Krijnen (RU Groningen), Dr. H. Bossert (HRS Management Consultants bv/VU Amsterdam) en Drs. M. Gelderman (VU Amsterdam) voor hun waardevol commentaar op een eerdere versie van dit artikel.
2 1) Omgevingsfactoren [zie o.a. Rockart, 1979; Hahn en Krystek, 1979; Leidecker en Bruno, 1984; Van Snellenberg, 1992a], 2) bedrijfstak [Anthony et al, 1989, 1992; Bungay en Goold, 1991; Lewy, 1992], 3) leveranciers [Kotler, 1991; Tjoe Nij en Bletz, 1993], 4) afnemers [Keuning en Eppink, 1987;

Tjoe Nij en Bletz, 1993], 5) concurrentiepositie [Rockart, 1979; Van Snellenberg, 1992a], 6) schaalgrootte [Lewy, 1992; Van Snellenberg, 1992a/b).

3 Het onderwerp ksf-en staat volop in de belangstelling van zowel het bedrijfsleven als de wetenschap. Binnen de KU Brabant vormen de auteurs van dit artikel een projectgroep die zich met theoretisch en empirisch onderzoek op dit gebied bezighoudt. Met voorliggend artikel willen zij geïnteresseerden prikkelen zich in een discussie over dit onderwerp te mengen. Voor reacties of meer informatie kunt $u$ telefonisch of schriftelijk contact opnemen met:

Dr. M.F.C.M. Wijn, KU Brabant, Faculteit der Economische Wetenschappen, Vakgroep Bedrijfseconomie/Sectie KWW, Postbus 90153, 5000 LE Tilburg

Telefoon : 013-662406/2315

Telefax : 013-663408 